\title{
A WHALING PIONEER
}

[Review by Arthur Credland* of Thomas Welcome Roys; American pioneer of modern whaling by F. P. Schmitt, C. de Jong and F. H. Winter. Charlottesville, Mariners Museum and University Press of Virginia, 1980, 235 p. Illus. US\$15.00.]

This is a very welcome publication describing the life and inventions of one of the least known of the 19th century whaling pioneers, Thomas Welcome Roys. He was born in 1816 and his first voyage as whaling master aged 25 yielded a cargo of oil and bone worth $\$ 40000$, an unprecedented sum. He went on to penetrate the Bering Strait and became the first to exploit systematically the stocks of Right Whales in the northern Pacific. Roys was interested in whale-killing devices. Congreve's method of shooting rocket harpoons, tested by William Scoresby $\mathrm{Sr}$ in 1821, must have greatly intrigued the inventive American. A Congreve rocket tube is preserved at Woolwich (apparently unknown to the authors) and undoubtedly became the prototype of Roys own rocket gun, a bazooka-like instrument shooting a barbed harpoon with an explosive head, patented in Britain in 1857. It was later to be replaced by Svend Foyn's explosive harpoon that forms the basis of modern whaling. Roys went on in partnership with Gustavus Lilliendahl to establish the first modern-style shore station on the east coast of Iceland to process rorqual whales caught by his vessels; he equipped his ships with the most up to date catching and processing equipment and designed the 'accumulator', which is usually credited to Foyn. But the venture finally failed due chiefly to the over-exuberant investment of capital into a series of brilliant ideas so that when success seemed close the supply of money had run out.

The chief source of information for Roys career is an unpublished memoir written shortly before his death and now preserved in the Suffolk County Whaling Museum, Long Island. Although the authors have recounted the events as told by Roys they have made little attempt to investigate the important British sources, other than the Patent Office specifications.

* Town Docks Muscum, Quecn Victoria Square, Kingston upon Hull, HU1 3RA.

\section{NATURAL HISTORY OF WHALES}

[Review by Robert Burton* of W. Nigel Bonncr's Whales. Poole, Blandford, 1980, 278 p, illus. Hardcover $£ 10.95$.]

Not many years ago whales were the concern of whalers and a few biologists, and the general public knew or cared little about them. This situation has now changed, and the fate of the whales has become an important topic of debate and demonstration. At the same time an interest has been generated in their natural history, especially in aspects of behaviour which suggest that whales may have 'higher' mental attributes. For biologists, the interest of whales lies more especially in their supreme adaptation to a marine lifestyle, and this is what Nigel Bonner sets out to convey.

An identically-named book by E. J. Slijper appeared, in translation, in 1962. In both, the title is used in the sense of all Cetacea. Slijper's volume became the cetologists' handbuok; it concentrated on the anatomy of adaptations because the state of knowledge then did not allow the author to expand on their functions. As a result of research in the intervening two decades much more is known, for instance, about how laminar flow enables dolphins to swim so fast and how they find their food by echo-location. The unique filtering mechanism used by the baleen whales to gather food can now be described in relation to the feeding habits of different species. In all, we are beginning to understand whales as living animals.

There are many aspects of whale biology which still remain a mystery. This is especially so in the field of behaviour and Bonner apologises for his scanty treatment of the subject. No apology is needed. Whereas the behaviour of many mammals is being studied in such depth that sophisticated statistical techniques are needed to interpret the data, information on whale behaviour is

* Manor Cotage, West Street, Great Gransden, Sandy, Bedfordshire SG19 3AU. 